\title{
Authority of Final Decision in Household Activities: Gender Perspective in Nepalese Society
}

\author{
Anita Shrestha ${ }^{1} \&$ Ritu Prasad Gartoulla ${ }^{2}$ \\ ${ }^{1} \mathrm{PhD}$ Scholar, Mewar University, Rajasthan, India \\ ${ }^{2}$ Retired Professor of Institute of Medicine, Tribhuvan University, Maharajgunj, Kathmandu
}

\section{Corresponding Author}

Anita Shrestha

Email: anitashrestha26@gmail.com

\begin{abstract}
Gender plays the significant role in decision making process in all types of society. Decision makers should have good leadership skill as well as should have adequate knowledge of concerned issue. In Nepalese society, decision is taken by the household head; either husband or wife. The study aims to identify the authority of final decision in household activities from the gender perspective in Nepalese society. The study was conducted among the 390 respondents of five ethnic groups: Newar, Magar, Tamang, Rai and Brahama/Chettri of Kathmandu valley. Simple random sampling technique was adopted to select the respondent considering the equal participation of male and female from all ethnic communities. The result shows that there was no significant difference in all ethnic groups regarding their participation in all types of decision making process.
\end{abstract}

\section{KEYWORDS}

Authority, Decision, Gender, Household, Nepal, Society

\section{INTRODUCTION}

Nepal is beautiful country from the natural beauty, cultural diversity, climate, language, caste and ethnicity. Nepalese society is still dominated by the cultural norms and values as well as religious thought. Family relation, kinship system, marriage system, gender participation and family decision is dominated by patriarchy system. Family head use to take the decision in family issue for all family members. From the gender perspective, national data shows the Population of Nepal as of the census day (June 22, 2011) stands at 26,494,504. Sex ratio (number of males per 100 females) at the national level has decreased from 99.8 in 2001 to 94.2 in 2011. In abstract number, there are 796,422 more females than males in the country. There are 125 caste/ethnic groups, 123 languages spoken as mother tongue and ten types of religion categories reported in census 2011 (Government of Nepal, 2012). The national report shows that 84.0 percentage of young women age 15-24 years who are able to read a short simple statement about everyday life or who attended secondary or higher education. 48.5 percentage of women age 20- 
49 years who were first married or in union before age 18 (Government of Nepal \& unicef, 2015). The subjective well-being indicators shows that 80.8 percentage of young women age 15 24 years who are very or somewhat satisfied with their life and 82.3 percentages are reported very or somewhat happy. Similarly, national report of Nepal shows that 57.0 percentage of young women age 15-24 years whose life improved during the last one year, and who expect that their life will be better after one year (Government of Nepal \& unicef, 2015).

It is customary everywhere to classify the human community on the basis of sex into groups of 'men' and 'women'. The biological fact of sex has created much difference between them. The aims and objectives, desires and aspirations, duties and responsibilities, dress styles and behavioral patterns, roles and status of men and women are different. Nowhere in the history of humanity were men and women treated alike and assigned statuses alike. Women have not been able to lead a life exactly on par with men in spite of their urge for equality (Rao, 2008, p. 813). Every society has some kinds of social rules and regulation. Some society has given power to male and in some society has given power to female. Gender participation in decision making process and final authority of decision in household activities is still issue of discussion in Nepalese society. In general, gender refers to the biological and social differences between men and women. Gender is a socio-economic and cultural construct for differentiating between roles, responsibilities, constraints, opportunities and needs of women and men in a given context. A basic distinction between men and women which is socially and culturally determined creates unequal power relation in our social life. Thus, an understanding of the unequal power relations between women and men is necessary to be familiar with the basic problems in gender relations. Power is directly related to gender with regard to the access, distribution and use of resources, which are unequally distributed between women and men (Sultana \& Lazim, 2011, p. 168). Nepalese society entertains strong traditional values in favor of males. Consequently, gender disparity is bound to be fundamentally very wide. A study has shown that despite higher attainment of literacy, social mobility and awareness, women still remain confined to their traditionally prescribed and socially acceptable roles, lower status and subordination to men within the patriarchal socio-cultural, economic, political and legal frameworks (Thapaliya, 2001, p. 15). Patriarchy, following Sylvia Walby (1990), is 'a system of social structures and practices in which men dominate, oppress and exploit women'. In such system men control women's labor power, reproduction, sexuality, mobility, and economic resources, including property (Bhasin, 1993, pp. 6-8).

Gradually, women empowerment and social inclusion program of Government of Nepal and other awareness program of non-governmental organizations have contributed in improvement in gender discrimination in social activities. It was during the 90's that the Government of Nepal started preparing policy measures to promote Gender Mainstreaming and Social Inclusion (GM/SI). Although the Government prepared various measures since the $6^{\text {th }}$ National Plan, most of them had no legislative basis. After the conclusion of the peace agreement in 2006, the Government prepared the Interim Constitution and Three Years Interim Plan in 2007, which contain directives and comprehensive frameworks for GM/SI. The Interim 
Constitution protects social rights of the disadvantaged including women, Dalits, Madhesis, indigenous ethnic tribes, children, the disabled, and those who are economically, socially, or culturally backward. It addresses rights to equality (Section 13), liability against discrimination (Section 14) and social justice to assure participation of those disadvantaged in the state mechanism (Section 21) (Bhattarai, 2008, p. 8). The Three Years Interim Plan on the other hand contains a chapter of GM/SI that shows policy frameworks in categories of the disadvantaged including women, Dalits, Adibasi Janajatis, Madhesis, Muslim, and the disabled. Each category includes long-term vision, objectives, indicators, strategies, major programs, expected outcomes, and estimated budgets ( International Development Center of Japan (IDCJ) \& International Development Associates Ltd.(IDeA), 2009, pp. 2-3).

There are different types of gender roles practiced by different caste and cultural. The study has focused on the decision making practice in different ethnic group of Nepal. There is work division between male and female. Males are assigned in outdoor activities whereas females are mainly assigned only for the indoor activities though female along cannot take final decision of indoor activities also. So considering these gender perspective, study aims to explore the authority of final decision in household activities in Nepalese context.

\section{MATERIALS \& METHOD}

The study is based on the descriptive study design. The data was collected from 390 respondents of the five ethnics groups of Kathmandu valley (Kathmandu, Lalitpur \& Bhaktpur district) of Nepal. Sample size was drawn by using the following sampling formula:

Here, $\mathrm{n}_{0}=$ is the sample size,

$$
n_{0}=\frac{Z^{2} p q}{e^{2}}
$$

$\mathrm{Z}^{2}=$ desired confidence level $(95 \%)$,

$\mathrm{e}=$ is the desired level of precision or the proportion of error

we are prepared to accept $( \pm 5 \%)$

$\mathrm{p}=$ is the estimated proportion of an attribute that is present in the population/prevalence/variability (.5) and $\mathrm{q}=$ is $1-\mathrm{p}$.

Simple random sampling technique was adopted to select the respondent. Equal participation of male and female was considered during the data collection. Household head was selected for the interview. Structured questionnaire was used for data collection after pre-testing to ensure the reliability and validity of instruments. Ethical consent was taken from the individual respondents.

\section{RESULTS \& DISCUSSION}

There was equal participation of male and female from all ethnic groups. As the objective of this study, discussion was held on authority of final decision on different types of issues in household level and out of house. 


\section{Family health care}

It is the general understanding that health is the primary need of people. Sound mind can live sound body so health awareness and care is must for all. With the growing number of educated people in family has also affected in the health seeking behavior. In case of child and old people in family, frequency of health post visit is increased and in such case female become more responsible and active in caring of such diseased people. The study also shows the comparatively higher number of female (wife) has authority of decision on family health care than male alone.

Table 1: Family health care

\begin{tabular}{|c|c|c|c|c|c|c|c|}
\hline \multicolumn{2}{|c|}{ Family health care } & \multicolumn{5}{|c|}{ Caste of Respondents } & \multirow[t]{2}{*}{ Total } \\
\hline & & \multirow{2}{*}{\begin{tabular}{|l|} 
Newar \\
14 \\
\end{tabular}} & \multirow{2}{*}{\begin{tabular}{|l|} 
Magar \\
7
\end{tabular}} & \multirow{2}{*}{\begin{tabular}{|l|} 
Tamang \\
14
\end{tabular}} & \multirow{2}{*}{\begin{tabular}{|l|}
$\begin{array}{l}\text { Rai } \\
\text { Limbu }\end{array}$ \\
31
\end{tabular}} & \multirow{2}{*}{$\begin{array}{l}\text { Brahmin or } \\
\text { Chhetri } \\
7\end{array}$} & \\
\hline Wife & Count & & & & & & 73 \\
\hline $8 \mathrm{rin}$ & $\%$ & $3.6 \%$ & $1.8 \%$ & $3.6 \%$ & $8.0 \%$ & $1.8 \%$ & $18.9 \%$ \\
\hline \multirow{2}{*}{ Husband } & Count & 3 & 3 & 2 & 4 & 4 & 16 \\
\hline & $\%$ & $0.8 \%$ & $0.8 \%$ & $0.5 \%$ & $1.0 \%$ & $1.0 \%$ & $4.1 \%$ \\
\hline \multirow{2}{*}{ Both } & Count & 59 & 64 & 61 & 42 & 67 & 293 \\
\hline & $\%$ & $15.3 \%$ & $16.6 \%$ & $15.8 \%$ & $10.9 \%$ & $17.4 \%$ & $75.9 \%$ \\
\hline \multirow{2}{*}{ Others } & Count & 2 & 2 & 0 & 0 & 0 & 4 \\
\hline & $\%$ & $0.5 \%$ & $0.5 \%$ & $0.0 \%$ & $0.0 \%$ & $0.0 \%$ & $1.0 \%$ \\
\hline \multirow{2}{*}{ Total } & Count & 78 & 76 & 77 & 77 & 78 & 386 \\
\hline & $\%$ & $20.2 \%$ & $19.7 \%$ & $19.9 \%$ & $19.9 \%$ & $20.2 \%$ & $100.0 \%$ \\
\hline
\end{tabular}

Sources: Field survey, 2014

Regarding family health care, $75.9 \%$ said that final decision was made by both husband and wife. Similarly, $18.9 \%$ said that wife (female) had final authority to decide about the care and treatment of family health followed by only $4.1 \%$ husband (male) had such authority. Only $1 \%$ said that other members of family had such authority to decide the care and treatment of family health care.

Caste wise, out of 386 respondents, 31 female of Rai/Limbu had authority followed by 14 females of Newar, 14 female of Tamang, 7 females of Magar and 7 females of Brahmin/Chhetri (Table 1)

In many part of the world, however, women receive less attention and health care than do men, and girls in particular often receive very much less support than boys. As a result of this gender bias, the mortality rates of females often exceed those of males (Sen, 2001, p. 470). The national health statistics of South Asian Country clearly indicate towards the preferential treatment of boys, particularly at young ages. This social reality is also manifested in the lives of young children in many different ways. Although the gender of a newborn does not necessarily impact the way a child is held, clothed or fed among middle and upper classes, there has been some evidences for a poorer quality of care for female children. This fact expresses itself in 
gender-specific statistics of survival and other health related statistics (Chaudhary, 2004, pp. 188-189).

\section{Making routine household purchases (basic goods)}

From the four fathers, indoor activities like management of daily household activities and its related decision is taken by the females. Males are responsible to manage the money for daily expenditure but how that money will be used and what types of goods will be purchased, is decided by the female. The general practice is supported by the data presented in the below Table 2, the majority of female had taken the decision of routine household purchase.

Table 2: Making routine household purchases

\begin{tabular}{|c|c|c|c|c|c|c|c|}
\hline \multicolumn{8}{|c|}{ Making routine household purchases (basic goods) } \\
\hline & & \multicolumn{5}{|c|}{ Caste of Respondents } & \multirow[t]{2}{*}{ Total } \\
\hline & & Newar & Magar & Tamang & $\begin{array}{ll}\text { Rai } & \text { or } \\
\text { Limbu } & \end{array}$ & $\begin{array}{l}\text { Brahmin or } \\
\text { Chhetri }\end{array}$ & \\
\hline \multirow{2}{*}{ Wife } & Count & 27 & 24 & 35 & 41 & 24 & 151 \\
\hline & $\%$ & $7.1 \%$ & $6.3 \%$ & $9.2 \%$ & $10.8 \%$ & $6.3 \%$ & $39.6 \%$ \\
\hline \multirow{2}{*}{ Husband } & Count & 6 & 10 & 6 & 5 & 3 & 30 \\
\hline & $\%$ & $1.6 \%$ & $2.6 \%$ & $1.6 \%$ & $1.3 \%$ & $0.8 \%$ & $7.9 \%$ \\
\hline \multirow{2}{*}{ Both } & Count & 39 & 36 & 28 & 29 & 46 & 178 \\
\hline & $\%$ & $10.2 \%$ & $9.4 \%$ & $7.3 \%$ & $7.6 \%$ & $12.1 \%$ & $46.7 \%$ \\
\hline \multirow{2}{*}{ Others } & Count & 6 & 1 & 8 & 2 & 5 & 22 \\
\hline & $\%$ & $1.6 \%$ & $0.3 \%$ & $2.1 \%$ & $0.5 \%$ & $1.3 \%$ & $5.8 \%$ \\
\hline \multirow{2}{*}{ Total } & Count & 78 & 71 & 77 & 77 & 78 & 381 \\
\hline & $\%$ & $20.5 \%$ & $18.6 \%$ & $20.2 \%$ & $20.2 \%$ & $20.5 \%$ & $100.0 \%$ \\
\hline
\end{tabular}

Sources: Field survey, 2014

Final decision on daily household level expenditure was made by $39.6 \%$ wife (females) followed by only $7.9 \%$ husbands (males). Similarly, $46.7 \%$ said that routine household purchase was decided by both husband and wife.

Caste wise, it was found that comparatively higher numbers of husband of Magar 2.6\% had authority of final decision on household purchases followed by only $0.8 \%$ husband of Brahmin/Chhetri community.

From the analysis of data and discussion with individual respondents, it was found that small scale daily routine expenditure is decided by female alone whereas big economic transition, purchasing of land, house or starting of business are decided by majority of male which clearly indicates the economic discrimination between male and female from the perspective of decision making. Previous literatures also show that in many societies, the ownership of property can also be very unequal. Even basic assets such as homes and land may be very asymmetrically shared. The absence of claims to property can not only reduce the voice 
of women, it can also make it harder for women to enter and to flourish in commercial, economic and even some social activities (Sen, 2001, p. 468).

\section{Children education}

People are day by day conscious about the importance of education for their children. In Nepalese society, children education is one major cause of rural to urban migration.

Table 3: Children education

\begin{tabular}{|c|c|c|c|c|c|c|c|}
\hline \multicolumn{8}{|c|}{ Children education } \\
\hline & & \multicolumn{5}{|c|}{ Caste of Respondents } & \multirow[t]{2}{*}{ Total } \\
\hline & & Newar & Magar & Tamang & $\begin{array}{ll}\text { Rai } & \text { or } \\
\text { Limbu } & \end{array}$ & \begin{tabular}{|l} 
Brahmin \\
Chhetri
\end{tabular} & \\
\hline \multirow{2}{*}{ Wife } & Count & 14 & 7 & 18 & 20 & 10 & 69 \\
\hline & $\%$ & $3.7 \%$ & $1.8 \%$ & $4.7 \%$ & $5.2 \%$ & $2.6 \%$ & $18.1 \%$ \\
\hline \multirow{2}{*}{ Husband } & Count & 2 & 4 & 4 & 6 & 3 & 19 \\
\hline & $\%$ & $0.5 \%$ & $1.0 \%$ & $1.0 \%$ & $1.6 \%$ & $0.8 \%$ & $5.0 \%$ \\
\hline \multirow{2}{*}{ Both } & Count & 61 & 61 & 52 & 51 & 63 & 288 \\
\hline & $\%$ & $16.0 \%$ & $16.0 \%$ & $13.6 \%$ & $13.4 \%$ & $16.5 \%$ & $75.4 \%$ \\
\hline \multirow{2}{*}{ Others } & Count & 0 & 1 & 3 & 0 & 2 & 6 \\
\hline & $\%$ & $0.0 \%$ & $0.3 \%$ & $0.8 \%$ & $0.0 \%$ & $0.5 \%$ & $1.6 \%$ \\
\hline \multirow{2}{*}{ Total } & Count & 77 & 73 & 77 & 77 & 78 & 382 \\
\hline & $\%$ & $20.2 \%$ & $19.1 \%$ & $20.2 \%$ & $20.2 \%$ & $20.4 \%$ & $100.0 \%$ \\
\hline
\end{tabular}

Sources: Field survey, 2014

Researcher had discussed with respondents regarding the authority of final decision made for the education of children. $75.4 \%$ respondents said that decision was made by both wife and husband mutually. Similarly, $18.1 \%$ said that authority of final decision was used to take by wife followed by $5 \%$ said it was taken by husband.

Caste wise, in total $18.1 \%$, only $1.8 \%$ female of Magar community had final authority as compared with $5.2 \%$ authority was hold by the wife of Rai/Limbu community (Table 3).

\section{Use of Family planning services}

The national data shows the Contraceptive prevalence rate that 49.6 percentage of women age 1549 years currently married or in union who are using (or whose partner is using) a (modern or traditional) contraceptive method (Government of Nepal \& unicef, 2015). Decision of use of family planning service depends upon the level of awareness about the benefit of family planning service as well as need of children. In Nepal, government and non-government organizations are implementing the family planning service program to aware the reproductive age group to prevent from the unwanted pregnancy and sexually transmitted diseases. the study aims to know the final decision on use of family planning services. 
Table 4: Use of Family planning services

\begin{tabular}{|c|c|c|c|c|c|c|c|}
\hline \multicolumn{8}{|c|}{ Use of Family planning services } \\
\hline & & \multicolumn{5}{|c|}{ Caste of Respondents } & \multirow{2}{*}{ Total } \\
\hline & & Newar & Magar & Tamang & $\begin{array}{ll}\text { Rai } & \text { or } \\
\text { Limbu }\end{array}$ & $\begin{array}{l}\text { Brahmin or } \\
\text { Chhetri }\end{array}$ & \\
\hline \multirow{2}{*}{ Wife } & Count & 5 & 3 & 5 & 4 & 3 & 20 \\
\hline & $\%$ & $1.3 \%$ & $0.8 \%$ & $1.3 \%$ & $1.0 \%$ & $0.8 \%$ & $5.2 \%$ \\
\hline \multirow{2}{*}{ Husband } & Count & 4 & 12 & 11 & 3 & 8 & 38 \\
\hline & $\%$ & $1.0 \%$ & $3.1 \%$ & $2.9 \%$ & $0.8 \%$ & $2.1 \%$ & $9.9 \%$ \\
\hline \multirow{2}{*}{ Both } & Count & 65 & 61 & 60 & 69 & 67 & 322 \\
\hline & $\%$ & $17.0 \%$ & $16.0 \%$ & $15.7 \%$ & $18.1 \%$ & $17.5 \%$ & $84.3 \%$ \\
\hline \multirow{2}{*}{ Others } & Count & 1 & 0 & 1 & 0 & 0 & 2 \\
\hline & $\%$ & $0.3 \%$ & $0.0 \%$ & $0.3 \%$ & $0.0 \%$ & $0.0 \%$ & $0.5 \%$ \\
\hline \multirow{2}{*}{ Total } & Count & 75 & 76 & 77 & 76 & 78 & 382 \\
\hline & $\%$ & $19.6 \%$ & $19.9 \%$ & $20.2 \%$ & $19.9 \%$ & $20.4 \%$ & $100.0 \%$ \\
\hline
\end{tabular}

Sources: Field survey, 2014

In total $84.3 \%$ respondents said that both husband and wife had authority of final decision of using of family planning services. Similarly, $9.9 \%$ husbands followed by $5.2 \%$ wife had authority of deciding the use of family planning services.

As compared only between the husband and wife, some disparity could be seen in Magar community $(0.8 \%$ wife and $3.1 \%$ husband had final authority) followed by Brahmin/Chhetri ( $0.8 \%$ wife and $2.1 \%$ husband) and Tamang (1.3\% wife and $2.9 \%$ husband) community (Table 4).

In general, it is good to know that there was mutual decision of husband and wife about the use of family planning services. The family planning services should be accepted by both husband and wife either it is adopted by wife or husband.

\section{Participation in public programs and activities}

In most of the Nepalese society, male domination was found in public program, basically in outdoor activities. in Nepalese society, there are some condition for women like during the time of menstruation, up to 1 year of husband death, up to 45 days of giving birth of child; women cannot participate in social and cultural program. But the study had collected the data in normal situation which shows the final authority of decision about the participation in public program from the household members. Basically household decides who will participate in the public program. 
Table 5: Participation in public programs and activities

\begin{tabular}{|c|c|c|c|c|c|c|c|}
\hline \multicolumn{8}{|c|}{ Participation in public programs and activities } \\
\hline & & \multicolumn{5}{|c|}{ Caste of Respondents } & \multirow[t]{2}{*}{ Total } \\
\hline & & Newar & Magar & Tamang & $\begin{array}{ll}\text { Rai } & \text { or } \\
\text { Limbu } & \end{array}$ & $\begin{array}{ll}\text { Brahmin } & \text { or } \\
\text { Chhetri } & \end{array}$ & \\
\hline \multirow{2}{*}{ Wife } & Count & 4 & 3 & 8 & 6 & 5 & 26 \\
\hline & $\%$ & $1.1 \%$ & $0.8 \%$ & $2.1 \%$ & $1.6 \%$ & $1.3 \%$ & $6.9 \%$ \\
\hline \multirow{2}{*}{ Husband } & Count & 24 & 39 & 36 & 26 & 21 & 146 \\
\hline & $\%$ & $6.3 \%$ & $10.3 \%$ & $9.5 \%$ & $6.9 \%$ & $5.6 \%$ & $38.6 \%$ \\
\hline \multirow{2}{*}{ Both } & Count & 35 & 25 & 24 & 39 & 41 & 164 \\
\hline & $\%$ & $9.3 \%$ & $6.6 \%$ & $6.3 \%$ & $10.3 \%$ & $10.8 \%$ & $43.4 \%$ \\
\hline \multirow{2}{*}{ Others } & Count & 13 & 5 & 9 & 5 & 10 & 42 \\
\hline & $\%$ & $3.4 \%$ & $1.3 \%$ & $2.4 \%$ & $1.3 \%$ & $2.6 \%$ & $11.1 \%$ \\
\hline \multirow{2}{*}{ Total } & Count & 76 & 72 & 77 & 76 & 77 & 378 \\
\hline & $\%$ & $20.1 \%$ & $19.0 \%$ & $20.4 \%$ & $20.1 \%$ & $20.4 \%$ & $100.0 \%$ \\
\hline
\end{tabular}

Sources: Field survey, 2014

The data (Table 5) shows that $38.6 \%$ husband followed by $6.9 \%$ wife had final authority to decide the participation in public program and activities. Similarly, $43.4 \%$ said that the both husband and wife mutually decided the participation. In general, there is some gap between the male and female to take the decision about the participation of family member in social program. Male has dominant roles in this context.

Caste wise, gender disparity was found high in Magar community $(0.8 \%$ wife followed by $10.3 \%$ husband had final authority) followed by $2.1 \%$ wife and $9.5 \%$ husband had final authority in Tamang community as compared with other castes groups.

\section{Decisions regarding economic transaction of the family}

Economic transaction means exchange of money, Bank deposit or withdraws sells and purchase of house or land. It is very general practice and found from the one to one discussion with participants also that still male dominance is high in majority household about the final decision of economic transaction. People think that female cannot afford to take the big decision without support of male but in case of women headed society; women do every decision of family and personal life.

Table 6: Decisions regarding economic transaction of the family Decisions regarding economic transaction of the family 
ISSN: 2362-1303 (Paper) | elSSN: 2362-1311(Online)

JOURNAL OF ADVANCED ACADEMIC RESEARCH (JAAR)

April 2017

\begin{tabular}{|c|c|c|c|c|c|c|c|}
\hline & \multicolumn{5}{|c|}{ Caste of Respondents } & \multirow[t]{2}{*}{ Total } \\
\hline & & Newar & Magar & Tamang & $\begin{array}{ll}\text { Rai } & \text { or } \\
\text { Limbu } & \end{array}$ & $\begin{array}{l}\text { Brahmin or } \\
\text { Chhetri }\end{array}$ & \\
\hline \multirow{2}{*}{ Wife } & Count & 4 & 4 & 4 & 3 & 3 & 18 \\
\hline & $\%$ & $1.1 \%$ & $1.1 \%$ & $1.1 \%$ & $0.8 \%$ & $0.8 \%$ & $4.8 \%$ \\
\hline \multirow{2}{*}{ Husband } & Count & 13 & 30 & 28 & 19 & 13 & 103 \\
\hline & $\%$ & $3.4 \%$ & $8.0 \%$ & $7.4 \%$ & $5.0 \%$ & $3.4 \%$ & $27.3 \%$ \\
\hline \multirow{2}{*}{ Both } & Count & 48 & 33 & 36 & 48 & 52 & 217 \\
\hline & $\%$ & $12.7 \%$ & $8.8 \%$ & $9.5 \%$ & $12.7 \%$ & $13.8 \%$ & $57.6 \%$ \\
\hline \multirow{2}{*}{ Others } & Count & 10 & 5 & 9 & 6 & 9 & 39 \\
\hline & $\%$ & $2.7 \%$ & $1.3 \%$ & $2.4 \%$ & $1.6 \%$ & $2.4 \%$ & $10.3 \%$ \\
\hline \multirow{2}{*}{ Total } & Count & 75 & 72 & 77 & 76 & 77 & 377 \\
\hline & $\%$ & $19.9 \%$ & $19.1 \%$ & $20.4 \%$ & $20.2 \%$ & $20.4 \%$ & $100.0 \%$ \\
\hline
\end{tabular}

Sources: Field survey, 2014

The data shows that $27.3 \%$ husband followed by $4.8 \%$ wife had authority of final decision on economic transaction of family. 57.6\% said that both wife and husband had equal authority of economic transaction (Table 6).

There was significant difference between the wives of five ethnic groups because minimum $0.8 \%$ to maximum $1.1 \%$ wife had authority of final decision. Similarly, $8 \%$ husband of Magar community had final decision followed by 3.4\% Newar and 3.4\% Brahmin/Chhetri community which show difference between Magar and Newar and Magar and Brahmin/Chhetri.

\section{Women should have right to participate in decision making process in household level}

Finally, researcher also asked about the division of authority between husband and wife regarding the participation in decision making process in household level discussion. The study did the perceptual analysis to know the perception of both male and female participants regarding the role of male and female in decision making process. Nepal government has also prepared the many policies, program and law to promote the participation of women in decision making level. At the national level the government policies have tried to respond to women's problems in various ways. The government had emphasized women's involvement in all programmes and projects for meetings their needs in all the sixth, seventh and eighth five year plans (1981-1995). The eight plans in particular mentioned about increasing women's presentations at decision making in the government, non-government and semi government sectors (Thapaliya, 2001, p. 17).

Table 7: Women participation in decision making process Women should have right to participate in decision making process in household level 
ISSN: 2362-1303 (Paper) | elSSN: 2362-1311(Online)

JOURNAL OF ADVANCED ACADEMIC RESEARCH (JAAR)

\begin{tabular}{|l|l|l|l|l|l|l|l|}
\hline \multicolumn{2}{|c|}{} & Newar & Magar & Tamang & $\begin{array}{l}\text { Rai } \\
\text { Limbu }\end{array}$ & $\begin{array}{l}\text { Brahmin } \\
\text { Chhetri }\end{array}$ & \\
\hline $\begin{array}{l}\text { Less than } \\
\text { Male }\end{array}$ & Count & 7 & 14 & 7 & 4 & 6 & 38 \\
\cline { 2 - 9 } & $\%$ of Total & $1.8 \%$ & $3.6 \%$ & $1.8 \%$ & $1.0 \%$ & $1.6 \%$ & $9.9 \%$ \\
\hline $\begin{array}{l}\text { Equal to } \\
\text { Male }\end{array}$ & Count & 70 & 64 & 69 & 74 & 65 & 342 \\
\hline \multirow{2}{*}{$\begin{array}{l}\text { More of Total } \\
\text { male than }\end{array}$} & $18.2 \%$ & $16.6 \%$ & $17.9 \%$ & $19.2 \%$ & $16.9 \%$ & $88.8 \%$ \\
\hline \multirow{2}{*}{ Total } & Count & 1 & 0 & 0 & 0 & 4 & 5 \\
\cline { 2 - 9 } & $\%$ of Total & $0.3 \%$ & $0.0 \%$ & $0.0 \%$ & $0.0 \%$ & $1.0 \%$ & $1.3 \%$ \\
\cline { 2 - 8 } & Count & 78 & 78 & 76 & 78 & 75 & 385 \\
\hline
\end{tabular}

Sources: Field survey, 2014

The data show that $88.8 \%$ said women should have equal power to male followed by 9.9\% said women should have rights to participate in decision making process less than male. Only $1.3 \%$ said that women should be given more rights than male. Caste wise, only $0.3 \%$ Newar and 1\% Brahmin/Chhetri said that women should be given more rights than male. Comparatively, more Magar community said that women should be given less right than male than the other ethnic groups (Table 7).

From the gender perspective, the study had selected the equal participation of male and female in study but result of the above data shows that higher number $(9.9 \%)$ of respondents opinioned that women should have less authority to participate in decision making process of household level activities than male whereas only $1.3 \%$ opinioned more than male. It indicates that in some cases, females also did not want more power than the male.

\section{CONCLUSIONS}

The study had comprised the five ethnic groups: Newar, Magar, Tamang, Rai and Brahama/Chettri of Kathmandu valley. All these groups have their own language and culture but there was no significant difference in practice of decision making either by husband or wife in all types of household activities. The maximum variation was found up to $4 \%$ in participation in all types of decision making process in all five ethnic groups. in general, small scale routine expenditure is decided by the female in all ethnic group whereas big scale like economic transaction, purchasing of land or house is decided by the male but it is good to know that majority of decision is made by the both husband and wife which indicates the increasing number of women participation in decision making process.

\section{REFERENCES}

International Development Center of Japan (IDCJ) \& International Development Associates Ltd.(IDeA). (2009). GENDER MAINSTREAMING AND SOCIAL INCLUSION PROJECT (GeMSIP). Kathmandu, Nepal: Ministry of Local Development, Ministry of Women, Children and Social Welfare and Japan International Cooperation Agency (JICA). 
ISSN: 2362-1303 (Paper) | elSSN: 2362-1311(Online)

JOURNAL OF ADVANCED ACADEMIC RESEARCH (JAAR)

Bhasin, K. (1993). What is Patriarchy? New Delhi.

Bhattarai, P. (2008). "Preliminary Study on Gender Mainstreaming and Social Inclusion Project (GM/SI) in Nepal: Kathmandu: JICA.

Chaudhary, N. (2004). Listening to Culture: Constructing Reality from Everyday Talk. New Delhi: Tejeshwor Singh for Sage Publications India Pvt. Ltd.

Government of Nepal \& unicef. (2015). Nepal Multiple Indicator Cluster Survey - 2014. National Planning Commission Secretariat, Central Bureau of Statistics. Kathmandu, Nepal: Government of Nepal and unicef.

Government of Nepal. (2012). National Populatio $n$ and Housing Census 2011. National Planning Commission Secretariat, Central $\mathrm{Bu}$ reau of Statistics . Kathmandu, Nepal: Government of Nepal.

Rao, C. N. (2008). Sociology: principles of sociology with an Introduction to Social Thought. Ram Nagar, New Delhi: S. Chand \& Company Ltd.

Sen, A. (2001, September 17). The Many Faces of Gender Inequality. The New Republic , 466477.

Sultana, A., \& Lazim, A. S. (2011). Gender Studies in Teacher Education: An Empirical Research. Asian Social Science, 7, No. 12;, 168-174.

Thapaliya, H. (2001). Gender Issues. In L. K. Bhattachan (Ed.), Gender and Democracy in Nepal (pp. 15-18). kathmandu, Nepal: Central Department of Home Science Women's Studies program Tribhuvan University.

Walby, S. (1990). Theorizing patriarchy. Oxford: Basil Blackwell. 